Volume 12(1), 2018

Page: 100-114

\title{
A Service Quality of Islamic Microfinance Institutions in Indonesia: An Importance-Performance Analysis Approach
}

\author{
Dety Nurfadilah ${ }^{1}$, Sudarmawan Samidi², Iwan Kurniawan Subagja ${ }^{3}$
}

\begin{abstract}
The rapid growth of financial system in Indonesia creates an intensive competition between Conventional and Islamic financial institutions. The study aims to evaluate the service quality of Islamic Microfinance Institution in Indonesia. The survey was carried out to acquire data from 126 respondents. Descriptive statistics and importance performance analysis (IPA) was used to analyze the data. The finding show that attributes plotted in quadrant "keep up the good work" are providing prompt service, and helpful response to customer requests, Ability in providing services to the customer as needed, prompt service on financial counselling, Ability of staff in giving proper explanation to the customer, Ability to keep the transaction process secure, and Sharia compliance banking products. Meanwhile, the attributes plotted in quadrant "concentrate here" are accessible of location of ATM, easy to access the location, ability to navigate customer to find what they intend, ability to maintain accuracy of bank statement, and ability in providing after sale services. To the best of author's knowledge, it is the first study that measuring the service quality of Islamic microfinance from customer perspective using importance-performance approach.
\end{abstract}

Keywords: Service Quality, Islamic microfinance, Importance-Performance Analysis

\begin{abstract}
Abstrak. Sistem keuangan di Indonesia berkembang pesat menciptakan persaingan yang intensif antara lembaga keuangan Syariah dan konvensional. Penelitian ini bertujuan untuk mengevaluasi kualitas layanan pada Lembaga Keuangan Mikro Syariah (LKMS) di Indonesia. Survei dilakukan untuk memperoleh data dari 126 responden. Statistik deskriptif dan importance performance analysis (IPA) digunakan untuk menganalisis data. Temuan ini juga menunjukkan bahwa atribut yang diplot dalam kuadran "tetap bekerja dengan baik" menyediakan layanan yang cepat, dan membantu dalam menanggapi permintaan pelanggan, kemampuan dalam memberikan layanan kepada pelanggan sesuai kebutuhan, layanan yang cepat dalam konseling keuangan, kemampuan staf dalam memberikan penjelasan yang tepat kepada pelanggan, kemampuan untuk menjaga proses transaksi yang aman, dan produk perbankan yang sesuai dengan prinsip syariah. Sementara itu, atribut yang diplot di kuadran "berkonsentrasi di sini" dapat diakses dari lokasi ATM, lokasi mudah diakses (strategis), kemampuan untuk menavigasi pelanggan dalam menemukan apa yang mereka perlukan, kemampuan untuk mempertahankan keakuratan pernyataan bank, dan kemampuan dalam menyediakan layanan setelah penjualan. Sepengetahuan penulis, ini adalah studi pertama yang mengukur kualitas LKMS dari perspektif pelanggan menggunakan IPA.
\end{abstract}

Kata kunci: Kualitas Layanan, keuangan mikro syariah, Importance-Performance Analysis

\footnotetext{
${ }^{1}$ Faculty of Economics, Universitas Krisnadwipayana|detynurfadilah@gmail.com

2 Faculty of Economics, Universitas Krisnadwipayana|sudarmawansamidi@gmail.com

${ }^{3}$ Faculty of Economics, Universitas Krisnadwipayana| iksubagja@gmail.com
} 


\section{Introduction}

Nowadays, Microfinance Institutions (MIs) is a fast growing business. The growth of Microfinance is expected to increase around 10-15\% in 2017 (Herger et al., 2016) and the number of MIs customers has reached approximately 130 million. The development of microfinance institutions has huge impact on many ways, for examples are improving the livelihoods, reducing vulnerability, and fostering social as well as economic empowerment. It give an equal access for woman and low-income people to have the same rights like others.

In Indonesia, the development of microfinance institutions has helped the business of many small and medium enterprises. The first microfinance institution, known as BRI, has been established in Indonesia since the 1977. It aimed to help the farmers, employees, and workers to escape from the trap of moneylenders, which provides credit with high interest rate. In the beginning of 1988, governments of Indonesia launched a policy about microfinance institutions which ended up being the emergence momentum for other Microfinance Institutions (MIs). Since then, the growth of microfinance institutions has helped in promoting economic growth and trying to reduce unemployment and poverty levels.

In a further development, microfinance institutions are growing by using the procedures of sharia law as the basis for its implementation. The activities of Islamic Microfinance Institutions (IMIs) are nearly equal to the conventional one, but they have differences in terms of principles, contract and transaction. Islamic banks offer financial services such as saving using wadiah contract, loans using mudarabah and musharakah, zakah, and other services which are based on free interest rate, gharar, and maysir.

After more than fifteen years, the number of Islamic microfinance institutions has developed and increased rapidly. The existence of Islamic banks has covers the entire territory of Indonesia with the largest population 
in the Java Islands. In addition to Java Islands, the larger population of Islamic banks are also located in South Sulawesi and West Nusa Tenggara. The rapid development of Islamic banks is caused by the high demand of financial access by low to medium income people in rural area. Nearly 125.5 million poor people in Indonesia have access to formal financial services. They are seeking for equal financial access and moneylenders-free. This development is also based on the fact that the existence of Islamic banking is still centered in urban communities and serves the efforts of middle and upper class, while most of the customers in Islamic banks are small and medium enterprises that relatively have limited access to the bank.

Table 1. Performance of Islamic Microfinance Institutions in Indonesia

\begin{tabular}{llccccc}
\hline $\begin{array}{c}\text { Types } \\
\text { of IMI }\end{array}$ & \multicolumn{1}{c}{ Indicator } & $\mathbf{2 0 1 0}$ & $\mathbf{2 0 1 1}$ & $\mathbf{2 0 1 2}$ & $\mathbf{2 0 1 3}$ & $\mathbf{2 0 1 4}$ \\
\hline Islamic & Total Assets & $2,738,745$ & $3,520,417$ & $4,698,952$ & $5,633,488$ & $6,573,574$ \\
Rural & Total Financing & $2,009,093$ & $2,675,930$ & $3,553,520$ & $4,433,492$ & $5,653,685$ \\
Banks & Total Banks & 150 & 155 & 158 & 163 & 163 \\
\hline Islamic & Total Assets & $30,102,876$ & $35,794,958$ & $51,422,543$ & $89,840,654$ & $105,800,344$ \\
Coopera & Total Institutions & 1,800 & 2,101 & 2,663 & 2,990 & 2,989 \\
tive & Total Financing & $17,748,276$ & $18,818,187$ & $19,495,622$ & $20,137,701$ & $20,948,854$ \\
(BMT) & & & & & & \\
\hline
\end{tabular}

Source: Financial Services Authority of Indonesia (2015)

According to table 1, the number of Islamic microfinance institutions has increased rapidly from 2010 to 2014. As we can see, the number of Islamic cooperative and BMT increased from 1,800 in 2010 to 2,989 in 2014, followed by the number of Islamic rural banks from 150 in 2010 to 163 in 2014. This development has triggered total asset and total financing. In 2010, the total assets of Islamic rural banks was IDR 2.73 million and increased to IDR 6.57 million in 2014, and then the total assets of Islamic cooperative and BMT increased from IDR 30.10 million in 2010 to IDR 105.80 million in 2014. The total financing of Islamic rural banks increased from IDR 2 million in 2010 to 
IDR 5.65 million in 2014, then the total financing of Islamic cooperative and BMT increased from IDR 17.74 million in 2010 to IDR 20.94 million in 2014.

However, Islamic Microfinance Institutions (IMIs) are currently facing multiple internal and external issues that hinder the process toward its independence. According to Amelia (2016), IMIs in Indonesia have poor performance and some of the institutions are consider bankrupt. According to Kuncoro (2017), there are many factors that influence their poor performance, namely low revenue, lack of supervision and reporting, lack of professional management, managers who do not follow the mandate would raise public distrust triggering withdrawals massive and difficult capital, Islamic microfinance institutions have a lower professional human resource compared to MFIs, low level of public confidence, limited infrastructure. In addition, less innovative product line and lower return compared to conventional counterparts would influence customer to switch to other banks. Therefore, the issue of service quality in Islamic microfinance institution must be considered as an important thing by the bank's practitioners in order to increase the volume of banks depositor and maintain its sustainability.

In line with this issue, the research aimed at evaluating the customer's perspective about the service quality of Islamic microfinance institutions. This research gives huge contribution to the development of Islamic microfinance institutions and reinforces previous research and serve as a reference for future researches. This research also provides information and knowledge for the practitioners about customer perception in Islamic microfinance institutions. This research is expected to assist practitioners to create a better strategy and increase the customer's self-confidence about Islamic products.

In line with this issue, the research aimed at evaluating the customer's perspective about the service quality of Islamic microfinance institutions. From the perspective of academics, this research assists student and academicians to acquire new knowledge and increase their skills in managing the company's performance, especially service quality. This research is also 
give huge contribution to the development of Islamic microfinance institutions and reinforce previous research and serve as a reference for future researches. From the context of practitioners, this research provides a clear picture about the ranking of service quality and the important area to be improved. It assists the practitioners to create a better strategy in service quality and provide a better way for IMIs to increase their competitive value.

This study is organized as follows: section 2 review the previous literature, section 3 state the theoretical framework, section 4 discuss about the research methods, section 5 analyze the meaningful findings, and section 6 conclude the paper.

\section{Literature Review}

According to Ledgerwood (1999), microfinance institutions, or more popularly called microfinance is defined as a financial provider for micro and small entrepreneurs as well as serve as a development tool for rural communities. Khadijah, et al. (2013) added that Islamic micro finance institutions is an optional institutions for people who have a low income to obtain financing in order to improve the standard of living and decrease poverty. Tohari (2003) also define Microfinance Institution (MFI) is an institution that provides financial services to micro-entrepreneurs and lowincome communities, formal, semi-formal, and informal. Thus Islamic microfinance institutions is a financial institution that provides financing to micro businesses run based on the provisions, principles and Islamic values.

According to Federal Ministry for Economic Cooperation and Development (2005) and Budhijana (2010), there are two types of Islamic microfinance institutions, namely Islamic Rural Banks (Bank Perkreditan Rakyat Syariah, BPRS) and Islamic Financial Cooperatives (Baitul Maal wat Tamwil, BMT). In Islamic rural banks, the business is operating under the same effective prudential regulation and supervision as commercial banks and conventional rural banks (BPR). After a promising start in the early 1990s, 
their development has since almost come to a standstill. Despite the fact that they have had only two years less than conventional BPR, they now comprise a mere $4 \%$ of the total number of rural banks, and $1.5 \%$ of the assets of the rural banking sector. In the Islamic financial, the regulation is not under the monetary authority but under the cooperative department. BMT is a cooperative legal entity.

In financial industry, service quality is very important because it is a major indicator of the customer satisfaction (Cronin and Taylor, 1992; Anderson and Sullivan, 1993; Taylor and Baker, 1994; Levesque and McDougall, 1996; Ali and Raza, 2015; Said, 2015). Bowen and Hedges (1993) agreed that good service quality will improve the customer satisfaction as well as expand market share (Shafie et al., 2004). Akhtar et al. (2011) added that the improvement of service quality will increase the competitive advantage in any industry.

Previous researchers found that customer satisfaction is a person's feeling towards a product or services. It may be a pleasure feeling or disappointment which influence customer behavior to buy or use again that product or services for many times. (Kotler, 1997; Owusu-Boateng, 2012, Akhtar et al., 2011). Bashir (2012) stated that customer will satisfy if the product or service has met their need and expectation. When the level of customer satisfaction increases, the level of customer loyalty will increase as well.

There have been many researchers who conducted research in the context of service quality towards customer satisfaction and customer loyalty in financial industry. Rokhman and Rivai (2014) evaluated the customer satisfaction on Indonesian Islamic microfinance. The study was used Structural Equation Modeling (SEM) and it found that there was positive impact of service quality towards Islamic microfinance in Indonesia.

Abduh and Othman (2014) evaluated the service quality of Islamic banks in UAE and found that the quick response about approval of financing, 
approval of new account, cost of services and products and purely Islamic working environment were plotted in Quadrant 1 (concentrate here). It showed that Islamic banks in UAE should improve their services on those areas to attract new customers and make sure that customers do not switch to other account. Thaker et al. (2016) conducted study about service quality of Islamic banks in Malaysia using IPA approach. The result showed that six attributes (website efficiency, sharia requirement, tangibility, assurance, reliability, responsiveness) play an important role in determining the customer satisfaction.

\section{Method}

Self-administered questionnaires were distributed to 250 respondents who are the existing customers of Islamic rural banks and Islamic cooperatives or previous customers who had an experience with the products from both institutions in Indonesia. However, there were only 126 valid data due to missing responses.

The survey instruments were divided into two sections. Section 1 provides the customer's demographic profile. Some of the anchors are: (1) Gender, (2) Age range, (3) Level of education, (4) Income per months, (5) time range to use products. Section 2 is followed by the IPA evaluation.

Researchers used a five point Likert scale to measure the importance (1 $=$ very unimportant to $5=$ very important $)$ and performance $(1=$ very unsatisfied to $5=$ very satisfied).

The Importance and Performance Analysis has been used many times by service industries such as banking (Abduh and Othman, 2014), government services (Wong et al. 2011), higher education (Silva and Fernandes, 2011), tourism (Go and Zhang, 2008)), health care (Dollinsky, 1991), restaurant services (Hsu, Byun, and Yang, 1997; Keyt, Yavas, and Riecken, 1994) and etc. IPA is a simple and superior tool to analyze 
customer's satisfaction and identify prioritize area for improvement (Martilla and James, 1977).

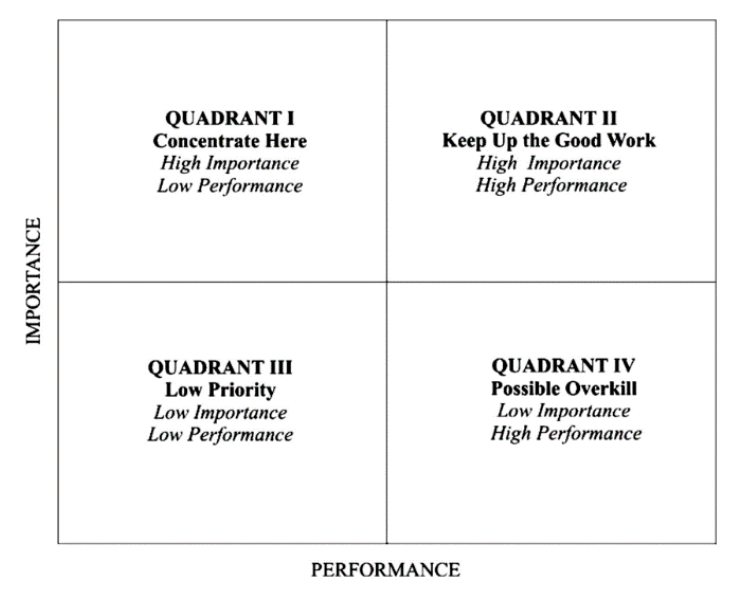

Figure 1. Importance-Performance Analysis

Source: Blešić et al. 2014

According to Blešić et al. (2014), the Y-axis indicates the importance of specific attributes, while $\mathrm{X}$-axis shows the service's performance. IPA framework is divided into four quadrants:

Quadrant I (Concentrate Here): an attribute that falls in this category is considered as high importance and low performance.

Quadrant II (Keep Up the Good Work): an attribute that falls in this category is considered as high importance and high performance.

Quadrant III (Low Priority): an attribute that falls in this category is considered as low importance and low performance.

Quadrant IV (Possible Overkill): an attribute that falls in this category is considered as low importance and high performance.

\section{Result and Discussion}

\section{Customers Demographic}

Table 2 below shows the demographic profile of the respondents which include gender, age, educational level, marital status, employment level, and annual income. From a total of 126 respondents, $60.3 \%$ of respondents are male and $39.7 \%$ of respondents are female. This finding shows that the 
number of male customers is higher than female customers. In addition, the highest percentage of respondent's age fall between 31-40 years old (57.9\%), while the lowest percentage fall between 20 years old and below (1.6\%). The finding also shows that $57.1 \%$ of respondents holding a bachelor degree and $27.0 \%$ of respondents holding SMA/SMK, while the lowest percentage of education is Ph.D. (0.8\%). From the point of marital status, the majority of respondents have married around $81.1 \%$ and the lowest proportion is divorced around $7.1 \%$. In the employment level, the highest percentage is selfemployed $(57.1 \%)$ and the lowest percentage is others (4.8\%). In the annual income, the majority of respondents earn income between IDR 40,000,001 IDR 60,000,000 (25.4\%) and the lowest percentage are IDR 20,000,000 - IDR 40,000,000 (I7.1\%).

Table 2. Demographic Profile

\begin{tabular}{llrlll}
\hline $\begin{array}{l}\text { Demographic } \\
\text { Variable }\end{array}$ & Category & $\%$ & $\begin{array}{l}\text { Demographic } \\
\text { Variable }\end{array}$ & Category & $\%$ \\
\hline Gender & Male & 60.3 & Marital & Single & \\
& Female & 39.7 & Status & Married & 11.1 \\
& & & & Divorced & 81.1 \\
\hline Age & 20 years and & 1.6 & Employment & Private sectors & 7.1 \\
\hline & below & 15.1 & Level & Public sector & 9.5 \\
& $21-30$ years & 57.0 & & Self-employed & 28.6 \\
& $31-40$ years & 25.4 & & Others & 57.1 \\
& $41-50$ years & & & & 4.8 \\
\hline Education & SMA/SMK & 27.0 & Annual & IDR 20,000,000 -IDR & 7.1 \\
& Bachelor Degree & 57.1 & Income & $40,000,000$ & \\
& Master Degree & 15.1 & & IDR 40,000,001 -IDR & 25.4 \\
& PhD & 0.8 & & $60,000,000$ & 21.4 \\
& & & & IDR 60,000,001 - IDR & \\
& & & & $80,000,000$ & 23.8 \\
& & & & IDR 80,000,001 - & \\
& & & & IDR100,000,000 & \\
& & & & Above IDR100,000,001 & 22.2 \\
& & & &
\end{tabular}




\section{Indonesia Islamic Microfinance Institution Attributes Ranking Analysis}

Table 3 shows the result of mean and their performance level from the customer's perspective towards Islamic microfinance institution's service quality in Indonesia. Customers ranked Easy to access the location (D12), Ability in providing services to the customer as needed (B4), Providing prompt service, and helpful response to customer requests (F16), Ability to maintain accuracy of bank statement (C8), and prompt service on financial counselling (F18) as the most importance attributes, while Ability in keeps all information confidentially (C9), Ability to provide proper facilities where customers' feel comfortable (D15), Ability in delivering accurate information to the customer (B5), Understand the needs of their customers (E14), Giving customers individual attention (E15) serves as the least importance attributes.

In the level of performance, customer ranked Providing prompt service, and helpful response to customer requests (F16), Ability in providing services to the customer as needed (B4), Ability in keeps all information confidentially (C9), Ability to keep the transaction process secure (C7), Sharia compliance banking products (A1) as the higher performance, while Easy to access the location (D12) Giving customers individual attention (E15), Ability in delivering accurate information to the customer (B5) serves as the lower performance in Islamic microfinance institutions in Indonesia.

Table 3. Attributes Ranking

\begin{tabular}{lcccc}
\hline \multicolumn{1}{c}{ Attributes } & Mean Imp. & Rank Imp. & Mean Per. & Rank Per. \\
\hline $\begin{array}{l}\text { A. } \text { Compliance } \\
1 \quad \text { Sharia compliance banking products }\end{array}$ & 4.1296 & 11 & 3.9603 & 5 \\
$2 \quad \begin{array}{l}\text { The product offered is based on } \\
\text { Islamic philosophy }\end{array}$ & 3.9603 & 13 & 3.4524 & 14 \\
$3 \quad \begin{array}{l}\text { The product offered is based on Al- } \\
\text { Qur'an and Sunnah }\end{array}$ & 4.0476 & 12 & 3.9276 & 8 \\
\hline $\begin{array}{l}\text { B. Assurance } \\
\text { Ability in providing services to the }\end{array}$ & 4.5587 & 2 & 4.0238 & 2 \\
$\quad$ customer as needed & & & &
\end{tabular}


TIFBR | Tazkia Islamic Finance and Business Review

Volume 12(1), 2018

\begin{tabular}{|c|c|c|c|c|c|}
\hline \multicolumn{2}{|r|}{ Attributes } & \multirow{2}{*}{$\begin{array}{c}\text { Mean Imp. } \\
3.5825\end{array}$} & \multirow{2}{*}{$\begin{array}{c}\text { Rank Imp. } \\
16\end{array}$} & \multirow{2}{*}{$\begin{array}{c}\text { Mean Per. } \\
3.3889\end{array}$} & \multirow{2}{*}{$\begin{array}{c}\text { Rank Per. } \\
18\end{array}$} \\
\hline 5 & $\begin{array}{l}\text { Ability in delivering accurate } \\
\text { information to the customer }\end{array}$ & & & & \\
\hline 6 & $\begin{array}{l}\text { Ability in providing after sale } \\
\text { services }\end{array}$ & 4.1507 & 10 & 3.5736 & 12 \\
\hline \multicolumn{6}{|c|}{ C. Reliability } \\
\hline 7 & $\begin{array}{l}\text { Ability to keep the transaction } \\
\text { process secure }\end{array}$ & 4.1665 & 7 & 3.9605 & 4 \\
\hline 8 & $\begin{array}{l}\text { Ability to maintain accuracy of bank } \\
\text { statement }\end{array}$ & 4.3413 & 4 & 3.6254 & 10 \\
\hline 9 & $\begin{array}{l}\text { Ability in keeps all information } \\
\text { confidentially }\end{array}$ & 3.9365 & 14 & 3.9703 & 3 \\
\hline \multicolumn{6}{|c|}{ D. Tangibility } \\
\hline 10 & $\begin{array}{l}\text { Ability to provide proper facilities } \\
\text { where customers' feel comfortable }\end{array}$ & 3.7548 & 15 & 3.5794 & 11 \\
\hline 11 & Accessible of Location of ATM & 4.1508 & 9 & 3.4762 & 13 \\
\hline & Easy to access the location & 4.6183 & 1 & 3.3452 & 16 \\
\hline \multicolumn{6}{|c|}{ E. Empathy } \\
\hline 13 & $\begin{array}{l}\text { Ability to assist customer to find } \\
\text { what they intend }\end{array}$ & 4.1587 & 8 & 3.3492 & 15 \\
\hline 14 & $\begin{array}{l}\text { Understand the needs of their } \\
\text { customers }\end{array}$ & 3.5476 & 17 & 3.9381 & 6 \\
\hline 15 & $\begin{array}{l}\text { Giving customers individual } \\
\text { attention }\end{array}$ & 3.4444 & 18 & 3.3413 & 17 \\
\hline \multicolumn{6}{|c|}{ F. Responsiveness } \\
\hline 16 & $\begin{array}{l}\text { Providing prompt service, and } \\
\text { helpful response to customer } \\
\text { requests }\end{array}$ & 4.5238 & 3 & 4.3968 & 1 \\
\hline 17 & $\begin{array}{l}\text { Ability of staff in giving proper } \\
\text { explanation to the customer }\end{array}$ & 4.1667 & 6 & 3.8968 & 9 \\
\hline 18 & $\begin{array}{l}\text { Prompt service on financial } \\
\text { counselling }\end{array}$ & 4.3193 & 5 & 3.9286 & 7 \\
\hline
\end{tabular}

\section{The Graphical Plotting of Attributes on The IPA Grid}

The map of IMI's service quality shows two important axes, X (level of satisfaction/performance) and $\mathrm{Y}$ (level of importance). The intersection is 
made using $X(3.7296)$ and $Y(4.0865)$. As can be seen, customer perceive accessible of location of ATM (D11), easy to access the location (D12), ability to assist customer to find what they intend (E13), ability to maintain accuracy of bank statement (C8), and ability in providing after sale services (B6) falling into quadrant 1 "concentrate here". It means that those attribute are very important, but the performance does not meet the customer satisfaction because the level of performance are below the average. Islamic microfinance institution should improve their services in this area, in order to attract more customers and increase their profitable. In quadrant II "keep up the good work", Providing prompt service, and helpful response to customer requests (F16), Ability in providing services to the customer as needed (B4), Prompt service on financial counselling (F18), Ability of staff in giving proper explanation to the customer (F17), Ability to keep the transaction process secure (C7), and Sharia compliance banking products (A1) are plotted as high performance and high importance. In quadrant III, The product offered is based on Islamic philosophy(A2), Ability to provide proper facilities where customers' feel comfortable (D10), Ability in delivering accurate information to the customer (B5), Giving customers individual attention (E15) are plotted as low priority quadrant. It means that customer perceive those attributes as low priority and low performance. In quadrant IV, Understand the needs of their customers (E14), Ability in keeps all information confidentially (C9), The product offered is based on Al-Quran and Sunnah (A3) are plotted at possible overkill which means that customer perceive those attributes as low performance and high importance. 


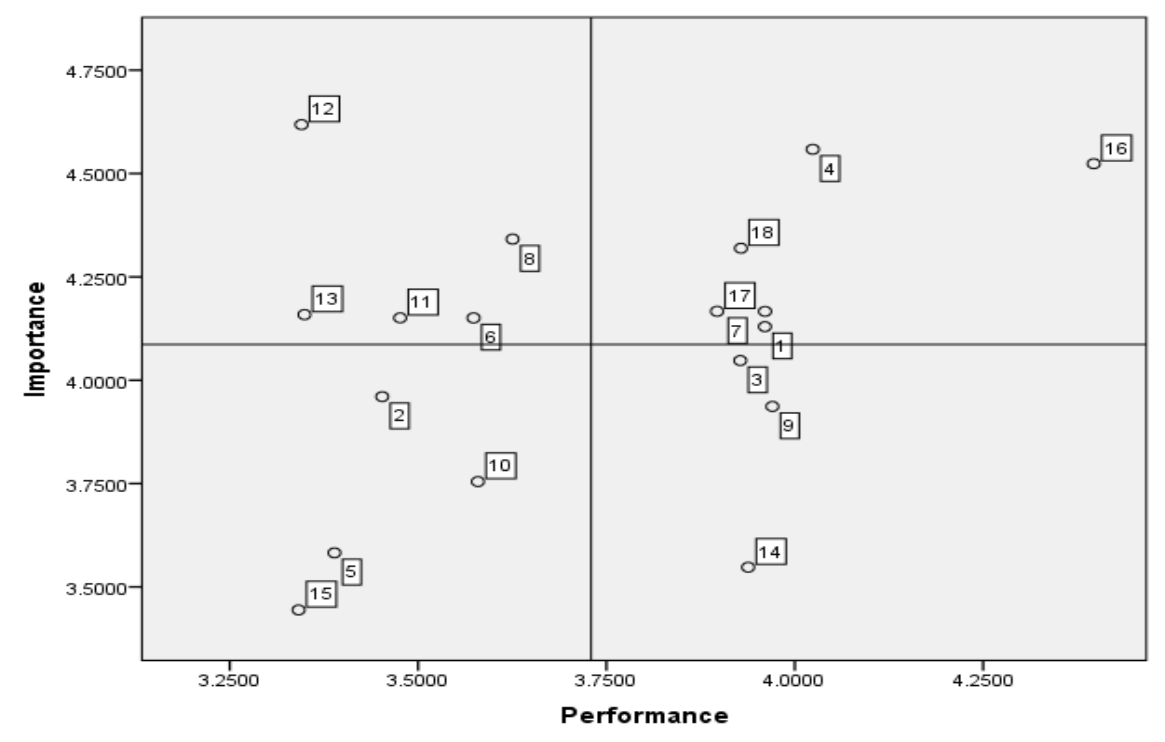

Figure 2. Map of Islamic Microfinance Institution's Service Quality

\section{Conclusion}

High competition between microfinance institutions and Islamic microfinance institutions has brought the attention of many practitioners and academicians to consider service quality as important indicator. Based on the finding, service quality does not only measure the relationship with customers, but it also measures other attributes, namely compliance, assurance, reliability, tangibility, empathy, and responsiveness.

According to Importance-performance analysis approach, there are five elements in the quadrant I (concentrate here), six elements in quadrant II (Keep up the good work), 4 elements I quadrant III (low priority), 3 elements in quadrant IV (possible overkill). Overall, the financing managed by Islamic Microfinance Institutions in Indonesia has been classified as effective, but there are some things that need to be corrected. IMIs should consider service after sale as one of the important indicator. It is a good way to assist customers in using their funding effectively, which could help IMIs generate repeat customers, increase brand loyalty, and ensure customer satisfaction. IMIs should be more transparent in providing accurate bank statement because it can increase customer's trust. In addition, providing a convenience 
services through ATM and accessible location are also compulsory to increase customer's satisfaction.

There are limitations in this study, especially the number of sample. The sample is still low compared to the number of population and the total clients of Islamic Microfinance in Indonesia. Besides that, most of the samples are moslem, even though it does not stated in the result. Therefore, future study is need to include more respondents from various religion and races, in order to get more generalized result.

\section{References}

Ali, M., and Ali Raza, S. (2015). Measurement of Service Quality Perception and Customer Satisfaction in Islamic Banks of Pakistan: Evidence from Modifies SERVQUAL Model. MPRA Paper.

Akhtar, M. N., Hunjra, A. I., and Akbar, S. W. (2011). Relationship Between Customer Satisfaction and Service Quality of Islamic Banks. World Applied Siences Journal, Vol. 13(3): 453-459.

Bashir, M. S. (2012). Analysis of Customer Satisfaction with the Islamic Banking Sector: Case of Brunei Darusallam. Asian Journal of Business and Management Sciences, Vol. 2(10): 38-50.

Dolinsky, A. (1991). Considering the Competition in Strategy Development: An Extension of Importance-Performance Analysis. Journal of Health Care Marketing, Vol. 11(1): 31-36.

Ferawati, R. (2015). Dampak Pembiayaan LKMS berdasarkan Garis Kemiskinan. Retrieved from http://fem.ipb.ac.id/d/iqtishodia/2015/Iqtishodia_20151126.pdf

Go, F. and Zhang, W. (2008). Applying Importance-Performance Analysis to Beijing as an International Meeting Destination. Journal of Travel Research, Vol. 35(1): 42-49.

Hacket, C. et al. (2015). The Future of World Religions: Population Growth Projections, 2010-2050. Pew Research Center. Washington DC.

Hsu, C. H. C., Byun, S., and Yang, I. S. (1997). Attitudes of Korean College Students Towards Quick-service, Family-style, and Fine Dining Restaurants. Journal of Restaurant and Foodservice Marketing, Vol. 2: 6585.

Ledgerwood, J. (1999). Microfinance Handbook: An Institutional and Financial Perspective. World Bank, Washington DC. 
Khadijah, S. et al. (2013). Sustainability of Islamic Micro Finance Institutions (IMFIs). Journal of Accounting and Finance. DOI. 10.13189/ujaf.2013.010205

Keyt, J. C., Yavas, U., and Riecken, G. (1994). Importance-Performance Analysis: A Case Study in Restaurant Positioning. International Journal of Retail and Distribution Management, Vol. 22: 35-40.

Levesqe, T., and Mcdouglas, G. H. G. (2005). Determinants of Customer Satisfaction in Retail Banking. International Journal of Bank Marketing, Vol. 14(7): 12-20.

Martilla, J. and James, J. (1977). Importance-Performance Analysis. Journal of Marketing, Vol. 41(1): 77-79.

Owusu-Boateng, K. (2012). An Assessment of Customer Satisfaction in the Microfinance Industry: A Case Study of Opportunity International Savings and Loans Limited. Ph.D Thesis. Kwame Nkrumah University of Science and Technology.

Seibel, H. D. and Wahyu, D. A. (2005). Sector Project Financial Systems Development Islamic Microfinance in Indonesia. World Bank Group, Eschborn.

Shafie, S., Asmi, W. N. W., and Haron, S. (2004). Adopting and Measuring Customer Service Quality in Islamic Banks; A Case Study of Bank Islam Malaysia Berhad, The Journal of Muamalat and Islamic Finance Research, Vol. 1(1).

Silva, F. H. and Fernandes, P. O. (2011). Importance-Performance Analysis As A Tool In Evaluating Higher Education Service Quality: The Empirical Results of Estig (IPB). Journal Creating Global Competitive Economics: A 360-Degree Approach: 306-315.

Thaker, H. M., Khaliq, A., and Thaker, M. A. (2016). Evaluating the Service Quality of Malaysian Islamic Banks: An Importance-Performance Analysis Approach. International Journal of Business and Information, Vol. 11(3).

Wong, M. S., Hideki, N., and George, P. (2011). The Use of ImportancePerformance Analysis (IPA) in Evaluating Japan E-Government Services. Journal of Theoretical and Applied Electronic Commerce Research, Vol. 6(2): 17-30. 